\title{
Linking Person Job Fit, Person Organization Fit and Organizational Culture to Employee Performance in Islamic Banks: the Mediating Role of Job Motivation
}

\author{
Windy Delvyana Wulandari \\ Universitas Muhammadiyah Yogyakarta, Indonesia
}

\section{Article History}

Received: December, $7^{\text {th }} 2021$ Revised: December, $18^{\text {th }} 2021$ Accepted: December, $20^{\text {th }} 2021$

\begin{abstract}
Corresponding

author:

E-mail:

windydelvyanawulan dari@gmail.com

Adaptability to the work environment affects employee's work attitude in the organization. This ability can be seen from the influence of person job fit, person organization fit, and organizational culture accumulating into employee work motivation. This study aims to examine the effect of person job fit, person organization fit and organizational culture on employee performance with work motivation as a mediating variable. The object of this research was BPRS Madina Yogyakarta and BPRS Bangun Drajat Warga Yogyakarta. In this quantitative research, the data were collected through a questionnaire distributed to employees of the two BPRS. The questionnaire involved 65 respondents and was analyzed using the SPSS 23 . The results showed a positive influence between person job fit on work motivation, person organization fit had no effect on work motivation, organizational culture had a positive effect on work motivation, work motivation had an effect on positive effect on employee performance, person job fit brought a positive effect on employee performance, person organization fit had no effect on employee performance, and organizational culture had no positive effect on employee performance.
\end{abstract}

Keywords: Mediating Model, Person Job Fit, Person Organization Fit, Organizational Culture, Path Analysis

\section{Introduction}

The development of Human Resources (HR) is one the most important objectives in an organization since it has a critical role in improving company performance. Hence, a feasible strategy is necessary for employee development, including recruitment, management until release/retirement. Pramesti (2013) explained that one of the vital steps to develop human

How to cite:

Wulandari, W. D. . (2021). Linking Person Job Fit, Person Organization Fit and Organizational Culture to Employee Performance in Islamic Banks: the Mediating Role of Job Motivation. Journal of Islamic Economic and Business Research, 1(2), 125-139. https://doi.org/10.18196/jiebr.v1i2.17 
Linking Person Job Fit, Person Organization Fit and Organizational Culture To Employee

Performance In Islamic Banks: The Mediating Role of Job Motivation

Windy Delvyana Wulandari

Page: 125-139

resources for performance improvement is through employee selection in the initial recruitment.

Employee selection is essential to achieve the goals of the organization (Pramesti, 2013). It aims to hire the right people on the right placements and acts as guidelines for companies to occupy the available positions (Atikawati \& Raswan, 2016). Also, it considers the suitability of employees with the work climate of an organization, where it may induce the employees to feel in harmony with their works, ease them to adjust, and finally give their all for the organization (Pramesti, 2013). The excellent performance of these employees will bring a tremendous impact on them. Thus, the organization highly values employees with considerable potential to create superior and competitive human resources and are able to achieve the goals of the organization (Utami \& Zakiy, 2020).

Performance is a behavior displayed by employees according to their role in an organization (Harahap \& Tirtayasa, 2020). Improving employee performance can be done by paying attention to person job fit, person organization fit, organizational culture, and work motivation. Person job fit is a concept of conformity between individual knowledge, skills, and abilities with job demands or individual needs with the job (Rizkia, 2020). Therefore, it is necessary to implement PJ-Fit in order to match with employees' abilities to motivate their performance in order to achieve the goals of an organization.

Person organization fit also contributes to increased employee performance. It is defined as the match between organizational values and individual values (Istanti, 2018). If PO-Fit is not well-implemented, employees will not feel in harmony with their work because the different values may negatively affect their performance. Accordingly, there is a need for conformity between individuals and the organization, so they can feel comfortable and motivated in bringing out their best efforts.

After person job fit and person organization fit, organizational culture may also affect employees' performance. As explained in Akob's research (2018), organizational culture has a positive effect on employee performance. The awareness of employees of the positive influence of organizational culture on employee performance can provide a strong motivation to maintain and develop the organizational culture so that they can become a strong impetus for organizational progress (Mewoh et al., 2017). Thus, the importance of the role of organizational culture in an organization is a trigger to create an emotional attachment between employees and the organization leading to good performance and achieving organizational goals (Sulastri et al., 2017).

As a result, the three factors above need to be considered by the manager of a company in improving employee performance. The manager must maintain employee performance and performance, among others, by motivating employees to carry out their duties in accordance with applicable regulations (Handayani et al., 2020). An employee with high motivation will treat his work as something valuable. Also, employees who do their jobs well and in accordance with the standards in an organization become a very valuable asset because of their significant contribution to achieving organizational goals (Puspita \& Zakiy, 2020). 
Linking Person Job Fit, Person Organization Fit and Organizational Culture To Employee

Performance In Islamic Banks: The Mediating Role of Job Motivation

Windy Delvyana Wulandari

Page: 125-139

This study used three independent variables of person job fit, person organization fit, and organizational culture since these three variables can affect the level of employee performance and work motivation. Besides, work motivation was the mediating variable in this study to see the indirect relationship between person job fit, person organization fit, and organizational culture on employee performance. Also, motivation may trigger the completion of a job, creating a good working atmosphere to adjust to the organization, maintain employee loyalty, increase discipline and reduce employee absenteeism (Setiawan, 2015). Thus, work motivation in an organization is necessary in order to improve employee performance to achieve the goals of the organization.

The research was conducted at Bank Pembiayaan Rakyat Syariah (BPRS) Madina and BPRS Bangun Derajat Warga because both BPRS are well-known in Yogyakarta and require to maintain service quality to customers. The increasing development of Islamic financial institutions in Indonesia requires human resources that can work well and be relied upon in order to realize the company's vision, mission, and goals (Zakiy, 2017). Many companies that recruit employees without paying attention to employees' abilities with employee work placements can result in decreased employee performance (Zakiy, 2021). Thus, BPRS Madina and BPRS Bangun Derajat Warga were chosen as the research objects.

\section{Literature Review}

\subsection{Person Job Fit}

Person job fit is a match between a person's needs and job characteristics or individual skills, personality, and job demands (Dari, 2019). Person job fit is defined as the compatibility between individuals and the jobs or tasks they perform in the workplace. This definition includes compatibility (ability) based on the needs of employees and the available work equipment to meet those needs, as well as job demands and the ability of employees to meet these demands (Bangun et al., 2017). Person job fit consists of demand abilities and need supply. Demand abilities are related to the knowledge, skills, and abilities of employees regarding the characteristics of the company, while need supply is related to job outcomes such as job satisfaction and career commitment.

\subsection{Person Organization Fit}

Person organization fit is the similarity of individual characteristics with organizational culture in building individual commitment and as individual guidelines in organizing (Hartina, 2020). According to Dari (2019), PO-fit is the level of conformity of the pattern between individual values and organizational values. Hence, individuals with a greater POfit will be easier to adjust to and more easily achieve job satisfaction than individuals with less. Person organization fit has four indicators: suitability of values, suitability of goals, fulfillment of employee needs, and suitability of personality culture characteristics (Putri, 2019).

\subsection{Organization Culture}

Organizational culture is the style of an organization that reflects the values or beliefs as guidelines for all members of the organization (Putri, 2019). Referring to the definition above, organizational culture is a way of life in an organization and can create patterns of 
Linking Person Job Fit, Person Organization Fit and Organizational Culture To Employee

Performance In Islamic Banks: The Mediating Role of Job Motivation

Windy Delvyana Wulandari

Page: 125-139

beliefs, values, and expectations that shape the character of an organization. According to Sari (2013), organizational culture has four indicators: leader behavior, prioritizing the company's mission, learning process, and motivation.

\subsection{Employee Performance}

Employee performance is the result of work in both quality and quantity by employees or behavior displayed in accordance with the responsibilities given to them (Nurcahyani \& Dewi, 2016). Consequently, employee performance is a person's overall level of success in carrying out work compared to various possibilities, such as standard target results or predetermined criteria that have been mutually agreed upon (Septarina, 2017). Thus, employee performance is an achievement of an employee to achieve the goals of an organization. The employee performance indicators, according to Safitri (2017), are divided into quantity, quality, and timeliness.

\subsection{Work Motivation}

According to Amiroso and Mulyanto (2015), motivation encourages someone to act in a certain way or develop in a certain way with a high desire to succeed. Musselman and John (1984) suggested that only unmet needs can motivate human behavior, while a need that has been fulfilled is no longer a motivation but may reappear as a motivator. According to Puspitasari (2014), indicators of work motivation are an encouragement to achieve goals, enthusiasm for work, initiative as well as creativity, and a sense of responsibility.

\subsection{Hypothesis Formulation}

\section{Influence of person job fit to work motivation}

According to the theory of person job fit, the suitability between the characteristics of the job and the individual's ability to carry out the work will strengthen the employee's bond to his work and may incite the employee to be more committed to the job (Putra, 2016). According to Stoner (1986), differences in job characteristics and individual characteristics can influence work motivation. Job characteristics can also affect performance, such as skill diversity (Ananda \& Sunuharyo, 2018). Previous research by Ananda and Sunuharyo (2018) showed that individual characteristics and job characteristics have a positive effect on work motivation. Therefore, the relationship between person job fit with individual characteristics and job characteristics lead to the following hypothesis:

\section{H1: Person job fit positively affects work motivation.}

\section{Influence of person organization fit to work motivation}

Person organization fit is broadly defined as the match between organizational values and individual values (Pramesti, 2013) and related to work motivation because PO-Fit in an organization makes employees feel in harmony with their work. Thus, they are motivated to always provide maximum performance in order to achieve the goals of the organization. Previous research by Pramesti (2013) proved that person organization fit has a positive effect on work motivation. Therefore, the second hypothesis is as follows: 
Linking Person Job Fit, Person Organization Fit and Organizational Culture To Employee

Performance In Islamic Banks: The Mediating Role of Job Motivation

Windy Delvyana Wulandari

Page: 125-139

\section{H2: Person organization fit has a positive effect on work motivation.}

\section{Influence of organizational culture on work motivation}

Organizational culture is a shared opinion held by fellow members of the organization, which then influences the way members of the organization work and behave (Putri, 2019). The said value system will be able to distinguish one organization from others. Also, it is related to work motivation because the existence of organizational culture in an organization can motivate employees to provide maximum performance in order to achieve goals in the organization. Research by Masitoh (2013) showed that organizational culture has a positive effect on work motivation. Another study by Akbar (2017) also supported organizational culture to bring a positive effect on work motivation. Therefore, the third hypothesis is as follows:

\section{H3: Organizational culture has a positive effect on work motivation.}

\section{Influence of work motivation on employee performance}

According to Robbins and Judge (2015), motivation is a process that explains the strength, direction, and persistence of a person to achieve goals. Motivation is related to the level of effort made by a person in achieving a goal and is closely related to the level of performance of an employee. Previous research by Sembiring (2020) emphasized that work motivation has a positive effect on employee performance. Giving work motivation to employees aims to increase morale, productivity, work discipline, work performance, and employees' sense of responsibility to the organization. Employee performance will improve if the company is able to motivate employees to work better along with a good work environment (Sembiring, 2020). Another study by Chisaan and Zakiy (2020) explained that good work motivation causes employees to be enthusiastic at work and increasing employee performance. Therefore, the next hypothesis is as follows:

\section{H4: Work motivation has a positive effect on employee performance.}

\section{Person job fit affects employee performance}

According to the theory of person job fit, the match between the characteristics of the job and the individual's ability to carry out the work will strengthen the employee's bond to his work. Hence the employee will be more committed to the job (Putra, 2016). If there is a match between the characteristics of an employee and the type of work, then the employee's performance tends to be high, and the level of pressure tends to be minimal. Furthermore, the lack of conformity will result in low performance and pressure in the system. A study by Rudy (2019) showed that person job fit has a positive effect on employee performance. Another study by Anatasya (2019) proved that person job fit has a positive effect on employee performance. Also, a study by Wahjudhy (2014) showed that person job fit has a positive effect on employee performance. Therefore, the fifth hypothesis is as follows:

\section{H5: Person job fit has a positive effect on employee performance}

\section{The effect of person organization fit on employee performance}

Person organization fit is broadly defined as the match between organizational values and individual values (Pramesti, 2013). Therefore, if the person organization fit in an 
Linking Person Job Fit, Person Organization Fit and Organizational Culture To Employee Performance In Islamic Banks: The Mediating Role of Job Motivation

Windy Delvyana Wulandari

Page: 125-139

organization will make employees feel comfortable and in harmony between their and their organization's values. Hence, the improved performance of employees may help to achieve the organizational goals. Previous research by Alfani dan Hadini (2017) showed that person organization fit has a positive effect on employee performance. Thus, the next hypothesis is as follows:

\section{H6: Person organization fit has a positive effect on employee performance.}

\section{The influence of organizational culture on employee performance}

Organizational culture is a guideline in an organization, and these opinions are able to create patterns of beliefs, values, and expectations so that it creates a character in an organization to distinguish it from other organizations (Putri, 2019). Dominant organizational culture to be realized by members of the organization may affect the values and norms that cover all business activities and may occur unintentionally. Culture can be a significant influence on a person's behavior and performance (Sutoro, 2020). Previous research by Sutoro (2020) explained that organizational culture has a positive effect on work motivation. The research also stated that a good organizational culture tends to make the institution strive for a better one. Accordingly, high work motivation can improve employee performance. Hence, the next hypothesis is as follows:

\section{H7: Organizational culture positively affects employee performance}

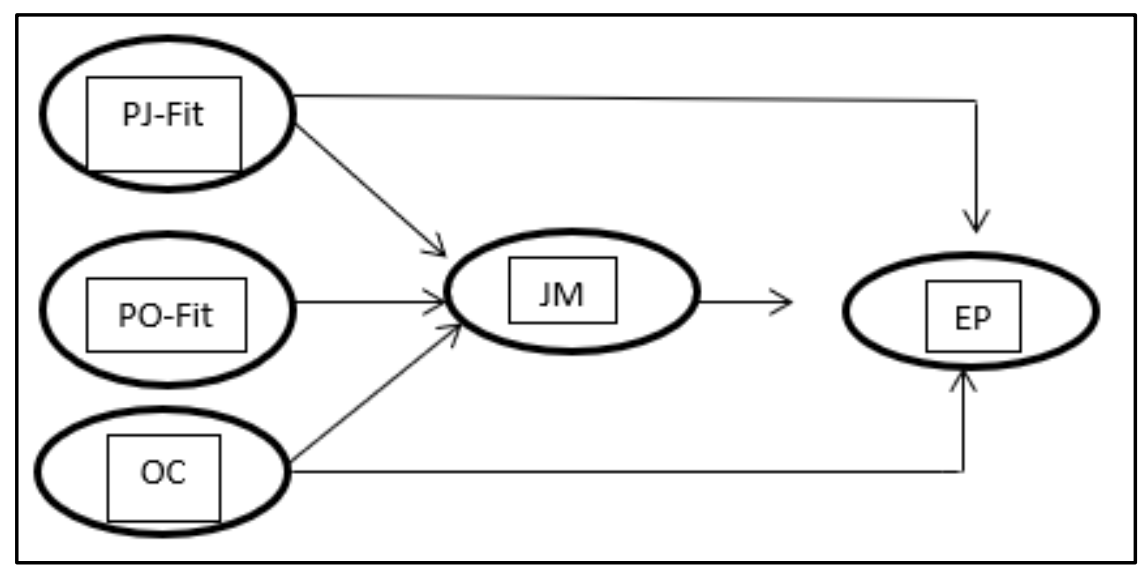

Figure 1. Research Model

\section{Research Methodologies}

\subsection{Samples and Procedures}

The population in this study were all employees at BPRS Madina Yogyakarta and BPRS Bangun Drajat Warga Yogyakarta. The sampling in this study used a non-probability sampling method, while the data collection used saturated sampling. Consequently, the number of samples in this study was 65 respondents. Meanwhile, the primary data were obtained through distributing questionnaires. 
Linking Person Job Fit, Person Organization Fit and Organizational Culture To Employee Performance In Islamic Banks: The Mediating Role of Job Motivation Windy Delvyana Wulandari Page: 125-139

\subsection{Measurement and Analysis}

This study applied a 5-point Likert scale measurement, 1 point for disagree and 5 point for strongly agree. After that, employees at BPRS Madina Yogyakarta and BPRS Bangun Drajat Warga Yogyakarta answered the statements in the questionnaire. The validity test was through using Pearson correlation by correlating items with the total items on the questionnaire. The reliability test in this study was by using Cronbach alpha. At the same time, the analytical tool in this study was path analysis.

\section{Person job fit}

Dari (2019) explained that person job fit is a match between a person's high needs and job characteristics or individual skills, personality, and job demands. There are two indicators (Amri, 2017) used in this variable, demand abilities and supply needs, related to the employee's ability to work. The variable of PJ-Fit was measured through 5 statement items developed by Dari, 2019. One of the statements in the questionnaire was, "I feel that the skills I have are in accordance with the demands of the job".

\section{Person organization fit}

According to Dari (2019), person organization fit is a match between the values of individuals and the values of the organization. There are four indicators, according to Hartina (2020), used in this variable: value suitability, goal suitability, employee needs fulfillment, and personality culture characteristics suitability related to the suitability of individual intrinsic values with the organization. The variable of PO-Fit was measured by 7 statement items developed by (Febe, 2016). One of the statements in the questionnaire was, "I know the company's values during the employee recruitment and selection process".

\section{Organizational Culture}

Putri (2019) stated that organizational culture is the style and way of life of an organization which is a reflection of the values or beliefs held by all members of the organization. There are four indicators, according to Sari (2013), used in this variable: leader behavior, prioritizing the company's mission, learning process, and motivation. Thus, the actions of a leader will usually be an important reflection for employees. The organizational culture variable was measured using 8 statement items developed by (Sari, 2013). One of the statements in the questionnaire was, "The leader reflects a good attitude and exemplary".

\section{Employee Performance}

Hamdiyah et al. (2016) employee performance is a result of work-related organizational goals such as quality, efficiency, and other work effectiveness criteria. This variable is measured using three indicators according to Safitri (2017), quantity, quality, and timeliness. Employee performance variables were measured using 10 statement items developed by (Ferryansyah, 2013). One of the statements in the questionnaire was, "I am able to complete all work correctly and perfectly".

\section{Work Motivation}

According to Amiroso and Mulyanto (2015), work motivation encourages someone to act in a certain way or develop in a certain way to succeed. There are four indicators, according to Puspitasari (2014), to measure work motivation variables: the drive to achieve goals, work 
Linking Person Job Fit, Person Organization Fit and Organizational Culture To Employee

Performance In Islamic Banks: The Mediating Role of Job Motivation

Windy Delvyana Wulandari

Page: 125-139

enthusiasm, initiative as well as creativity, and a sense of responsibility. Someone with high work motivation has a strong drive in him to achieve maximum performance and eventually affect the goals of an organization. The work motivation variable was measured using 8 statement items developed by (Puspitasari, 2014). One of the statements in the questionnaire was "I always work full of calculations so that the work is completed according to its purpose".

\section{Results and Analysis}

\subsection{Instrument Test}

In this study, after testing the validity of all indicators, the statements were declared valid with a correlation $r$ count $>r$ table (Sugiyono, 2017), with a value of 0.244 . Based on the reliability test of all statements, it was stated reliable with Cronbach alpha value of 0.06 . Thus, the measurement results were consistent and could be used to process the data.

\subsection{Hypothesis Testing (Path Analysis) First regression analysis}

The results of the first regression analysis were used to determine the effect of person job fit, person organization fit, and organizational culture on work motivation variables formulated as $\mathrm{Z}=\beta \mathrm{o}+\beta 1 \mathrm{X} 1+\beta 2 \mathrm{X} 2+\beta 3 \mathrm{X} 3+\varepsilon$. The results are in the following table:

Table 1. First Regression Analysis Coefficients $^{\mathbf{a}}$

\begin{tabular}{|c|c|c|c|c|c|c|}
\hline & \multirow[t]{2}{*}{ Model } & \multicolumn{2}{|c|}{$\begin{array}{l}\text { Unstandardized } \\
\text { Coefficients }\end{array}$} & \multirow{2}{*}{$\begin{array}{l}\text { Standardized } \\
\text { Coefficients } \\
\text { Beta }\end{array}$} & \multirow[t]{2}{*}{$\mathrm{t}$} & \multirow[t]{2}{*}{ Sig. } \\
\hline & & B & Std. Error & & & \\
\hline \multirow{4}{*}{1} & (Constant) & 5.682 & 3.306 & & 1.719 & .091 \\
\hline & PJ & .463 & .155 & .312 & 2.980 & .004 \\
\hline & PO & .184 & .135 & .177 & 1.363 & .178 \\
\hline & BO & .397 & .144 & .364 & 2.760 & .008 \\
\hline
\end{tabular}

a. Dependent Variable: MK

Table 1 shows that the regression model is $Z=5,682+0,463 X 1+0,184 X 2+0,397 X 3+0,519$. It can be seen that the significance value of person job fit is $0.004<0.05$, while person organization fit is $0.178<0.05$, and organizational culture of $0.008<0.05$. Therefore, person job fit, person organization fit and organizational culture affect work motivation.

Table 2. First Regression Summary Model Model Summary

\begin{tabular}{ccccc}
\hline Model & R & R Square & Adjusted R Square & Std. Error of the Estimate \\
\hline 1 & $.721^{\mathrm{a}}$ & .520 & .496 & 2.52501 \\
\hline
\end{tabular}

Based on table 2 above, the Adjusted R Square value was 0.496. It explained that the contribution of independent and mediator variables was $49.6 \%$, while the remaining $50.4 \%$ were the contribution of other variables not included in the study. 
Linking Person Job Fit, Person Organization Fit and Organizational Culture To Employee

Performance In Islamic Banks: The Mediating Role of Job Motivation

Windy Delvyana Wulandari

Page: 125-139

Hypothesis 1 stated that person job fit has a positive effect on work motivation. The results of path analysis calculations show that person job fit has a positive effect on work motivation with a coefficient value of 0.312 . The significance value of the person job fit variable on work motivation shows the number 0.004 below 0.05 , which means that the person job fit variable has an influence on work motivation. These results indicate that hypothesis 1 is supported. The result is in line with Ananda and Sunuharyo (2018) that person job fit has a positive effect on work motivation. Thus, the suitability of work placement with employee skills can increase work motivation because they will feel comfortable in doing their works suited to employee skills.

Hypothesis 2 stated that person organization fit has a positive effect on work motivation. The results of path analysis calculations show that person organization fit does not have a positive effect on work motivation with a coefficient value of 0.177 . The significance value of the person organization fit variable on work motivation shows the number 0.178 above 0.05 , which means that the person organization fit variable has no effect on work motivation. Thus, hypothesis 2 was rejected. Also, research by Wulandari and Tjahjaningsih (2017) stated that person organization fit does not have a positive effect on work motivation.

Hypothesis 3 stated that organizational culture has a positive effect on work motivation. The results of path analysis calculations show that organizational culture has a positive effect on work motivation with a coefficient value of 0.364 . The significance value of the organizational culture variable on work motivation shows that the number 0.008 below 0.05 , which means that the organizational culture variable has an influence on work motivation. These results indicate that hypothesis 3 was supported. The result is supported by Akbar's research (2017) that organizational culture has a positive effect on work motivation.

\section{Second regression analysis}

The results of the second equation were used to determine the effect of person job fit, person organization fit, organizational culture, and work motivation on employee performance and formulated as $\mathrm{Y}=\beta \mathrm{o}+\beta 1 \mathrm{X} 1+\beta 2 \mathrm{X} 2+\beta 3 \mathrm{X} 3+\beta 4 \mathrm{Z}+\varepsilon 2$. The results of the second regression analysis were as follows:

Table 3. Second Regression Results

\begin{tabular}{|c|c|c|c|c|c|c|}
\hline \multicolumn{7}{|c|}{ Coefficients $^{\mathbf{a}}$} \\
\hline & \multirow{2}{*}{ Model } & $\begin{array}{r}\text { Unsta } \\
\mathrm{Co}\end{array}$ & $\begin{array}{l}\text { ardized } \\
\text { cients }\end{array}$ & $\begin{array}{c}\text { Standardized } \\
\text { Coefficients }\end{array}$ & \multirow{2}{*}{$\mathrm{t}$} & \multirow{2}{*}{ Sig. } \\
\hline & & $\mathrm{B}$ & Std. Error & Beta & & \\
\hline \multirow{5}{*}{1} & (Constant) & 10.241 & 2.923 & & 3.503 & .001 \\
\hline & $\mathrm{PJ}$ & .419 & .144 & .278 & 2.916 & .005 \\
\hline & PO & .006 & .118 & .006 & .050 & .960 \\
\hline & BO & .175 & .132 & .159 & 1.331 & .188 \\
\hline & MK & .501 & .111 & .494 & 4.530 & .000 \\
\hline
\end{tabular}

a. Dependent Variable: KK 
Linking Person Job Fit, Person Organization Fit and Organizational Culture To Employee

Performance In Islamic Banks: The Mediating Role of Job Motivation

Windy Delvyana Wulandari

Page: 125-139

Based on table 3, the regression equation model was as follows:

$Y=10.241+0,419+0,006+0,175+0,501+0,585$

Referring to the second model, the significance value of person job fit was $0.005<0.05$, person organization fit was $0.960>0.05$, organizational culture was $0.188>0.05$ and work motivation was $0.000<0.05$. Thus, person job fit affects employee performance, person organization fit does not affect employee performance, organizational culture does not affect employee performance, and work motivation affects employee performance.

Table 4. Second Regression Sumarry Model

Summaryb Model

\begin{tabular}{ccccc}
\hline Model & R & R Square & Adjusted R Square & Std. Error of the Estimate \\
\hline 1 & $.811^{\mathrm{a}}$ & .657 & .635 & 2.18079 \\
\hline
\end{tabular}

a. Predictors: (Constant), MK, PJ, PO, BO

Based on table 4, the Adjusted R Square value was 0.635 . As a result, the contribution of independent and mediator variables on the dependent variable was $63.5 \%$, while the remaining $36.5 \%$ were the contribution of other variables not included in the study.

Hypothesis 4 stated that work motivation has a positive effect on employee performance. The results of path analysis calculations showed that work motivation has a positive effect on employee performance with a coefficient value of 0.494 . The significance value of the work motivation variable on employee performance shows the number 0.000 was below 0.05 , meaning that the work motivation variable has an influence on employee performance. These results indicated that hypothesis 4 was supported. The results are supported by Sembiring's research (2020) that work motivation has a positive effect on employee performance.

Hypothesis 5 stated that person job fit has a positive effect on employee performance. The results of path analysis calculations showed that person job fit has a positive effect on employee performance with a coefficient value of 0.278 . The significance value of the work motivation variable on employee performance shows the number 0.005 below 0.05 , which means that the person organization fit variable has an influence on employee performance. These results indicated that hypothesis 5 was supported. It is supported by research by Anatasya (2019) that person job fit has a positive effect on employee performance.

Hypothesis 6 stated that person organization fit has a positive effect on employee performance. The results of path analysis calculations show that person job fit does not have a positive effect on employee performance, with a coefficient value of 0.006 . The significance value of the person organization fit variable on employee performance showed the number 0.960 above 0.05 , which means that the person organization fit variable has no effect on employee performance. These results indicated that hypothesis 6 was not supported. This is supported by research by Hanafi et al. (2018) that person organization fit does not have a positive effect on employee performance.

Hypothesis 7 stated that organizational culture has a positive effect on employee performance. The results of path analysis calculations showed that organizational culture 
Linking Person Job Fit, Person Organization Fit and Organizational Culture To Employee

Performance In Islamic Banks: The Mediating Role of Job Motivation

Windy Delvyana Wulandari

Page: 125-139

does not have a positive effect on employee performance with a coefficient value of 0.159 . The significance value of the organizational culture variable on employee performance shows the number 0.188 above 0.05 which means that the organizational culture variable has no influence on employee performance. These results indicate that hypothesis 7 was not supported. This is supported by research by Sasongko et al., (2021) which states that organizational culture does not have a positive effect on employee performance.

\subsection{Discussions}

Based on the tests, person job fit has a positive influence on work motivation. This is supported by research by Ananda and Sunuharyo (2018) that person job fit has a positive effect on work motivation. The results showed that the suitability of work placement with employee skills could increase work motivation since employees will feel more comfortable in doing work if it is in accordance with employee skills.

Based on the tests, person organization fit does not have a positive effect on work motivation. This is supported by research by Wulandari and Tjahjaningsih (2017) that person organization fit does not have a positive effect on work motivation because the suitability of employees with their organization does not necessarily affect their work motivation for several reasons. First, compatibility with the organization does not change the way an employee works as much as person job fit, which is very dependent and binding on employees because work is part of the daily work of employees to be done while person organization fit does not directly affect the work of employees. Second, employees do not always pay attention to conformity with the organization to get work motivation because working productively to achieve common goals in the organization is unrelated to work motivation.

Based on the tests, organizational culture has a positive influence on work motivation. This is supported by Akbar's research (2017) that organizational culture has a positive effect on work motivation. Also, organizational culture, according to Putri (2019), is the style and way of life of an organization which is a reflection of the values of trust and becoming the guidelines for all employees in the organization. This point has been applied well by the two BPRS to increase work motivation for employees.

Based on the tests, work motivation has a positive influence on employee performance. This is supported by Sembiring's research (2020) that work motivation has a positive effect on employee performance. This is because work motivation is the driving force of an employee and is valued by the organization. It can be said that, in this case, high motivation will be able to improve good performance as well as to achieve the goals of the organization.

Based on the tests, person job fit has a positive influence on employee performance. This is supported by research by Anatasya (2019) that person job fit has a positive effect on employee performance. This is because the suitability of employees with their work in an organization can improve employee performance to achieve common goals in an organization. The suitability of employees with their work will also make employees in an organization feel comfortable in carrying out their obligations. 
Linking Person Job Fit, Person Organization Fit and Organizational Culture To Employee

Performance In Islamic Banks: The Mediating Role of Job Motivation

Windy Delvyana Wulandari

Page: 125-139

Based on the tests, person organization fit has no effect on employee performance. This is supported by research by Hanafi et al. (2018) that person organization fit does not have a positive effect on employee performance. This is because the value match for employees is not a benchmark for improving employee performance. Therefore, employees at both BPRS only pay attention to their respective job desks because it has become an employee's daily job to be able to complete their duties. In comparison, person organization fit cannot affect the work of employees. In addition, employees also feel that it is not only the suitability between employees and the organization that becomes a benchmark for improving performance but can be seen from the person job fit.

Based on the tests, organizational culture does not have a positive influence on employee performance. This is supported by the research of Sasongko et al. (2021) that organizational culture does not have a positive effect on employee performance. This is because the organizational culture for employees at the two BPRS is just a slogan to remind how the work culture of the organization but not applied directly as an implicit order nor be implemented in the daily work of employees. It can be said that organizational culture cannot affect employee performance.

\section{Conclusions}

Based on the above analysis and discussion, the person job fit has an influence on work motivation, person organization fit has no effect on work motivation, organizational culture has an influence on work motivation, work motivation has an influence on employee performance, person job fit has an influence on employee performance, person organization fit has no effect on employee performance and organizational culture has no influence on employee performance.

\subsection{Research Limitation}

1. In this study, there were many limitations of respondents in the study. Further research should expand the range of respondents.

2. The sampling in this study was a saturated sample. The questionnaire distribution was done through the company, so not all employees have the opportunity to become respondents. The results of the questionnaire in this study were also solely based on the answers.

\subsection{Managerial Implications}

Based on the results, person job fit has a positive effect on work motivation, organizational culture has a positive effect on work motivation, work motivation has a positive effect on employee performance, and person job fit has a positive effect on employee performance. From these results, managers of BPRS Madina Yogyakarta and BPRS Bangun Drajat Warga Yogyakarta should pay more attention to and control person job fit, organizational culture, and work motivation by paying more attention to employee comfort at work, improving organizational climate, analyzing assignments, increasing participation in decision making, improve an organizational culture that is less suitable for employees, and providing effective direction for employees. Hopefully, those improvements may make employees 
Linking Person Job Fit, Person Organization Fit and Organizational Culture To Employee

Performance In Islamic Banks: The Mediating Role of Job Motivation

Windy Delvyana Wulandari

Page: 125-139

happy and comfortable with the work. Hence they can improve their performance and ultimately achieve organizational goals.

This section consists of recommendations for practitioner, regulator and academician, based on the findings of this study.

\section{References}

Akbar, Taufik. (2017). Analisis Pengaruh Budaya Organisasi Terhadap Motivasi Kerja Pada Pegawai Dinas Kesehatan Kabupaten Pegunungan Bintang Provinsi Papua. Jurnal Unisri. Vol. 4 No. 2

Akob, M. (2018). Analisis Etika Kerja Islam, Budaya Organisasi, Komitmen Organisasi dan Kompetensi Sumber Daya Manusia terhadap Kinerja Karyawan (Studi Empiris pada Karyawan Perbankan Syariah di Indonesia ). Jurnal Ilmu Sosial Dan Ilmu Politik, 80101.

Amiroso, J. dan Mulyanto. (2015). Influence of Discipline, Working Environment, Culture of Organization and Competence on Workers Performance through Motivation, Job Satisfaction. Journal of Business and Management. Vol.7, No.36.

Ananda, S, S dan B. S. Sunuharyo. (2018). Pengaruh Karakteristik Individu Dan Karaktristik Pekerjaan Terhadap Kinerja Karyawan Dengan Variabel Mediator Motivasi Kerja Karyawan. Jurnal Administrasi Bisnis. Vol. 58 No. 1

Anatasya, A. (2019). Analisis Pengaruh Person Organization Fit dan Person Job Fit terhadap Kinerja Pegawai melalui Komitmen Afektif. Jurnal Ilmu Manajemen (JIM). 97-105.

Atikawati Ena dan Raswan U. (2016). Strategi Rekruitmen Dan Seleksi Terhadap Kinerja Karyawan. Jurnal Perilaku Dan Strategi Bisnis. Vol. 4 No.1

Bangun, V. G.supartha dan S. Made. (2017). Pengaruh Person Job Fit dan Person Organization Fit Terhadap Komitmen organizational dan Organizational Citizhenship Behavior ( OCB ). Jurnal Ekonomi dan Bisnis. Vol. 06 No 05.

Chisaan, A. R., \& Zakiy, M. (2020). Employee Stock Ownership As Strategy To Improve Employee Performance (Case of Bank Syariah Mandiri Yogyakarta). Jurnal Ekonomi Dan Bisnis Islam (Journal of Islamic Economics and Business), 6(1), 42. https://doi.org/10.20473/jebis.v6i1.14873

Dari, D. U. (2019). Pengaruh Person-Job Fit \& Person-Organization Fit terhadap Job Satisfaction Dimediasi oleh Emotional Labor pada Perawat. Tesis UNAIR

Handayani, S. H. S., dan F. Fauziah. (2020). Upaya Peningkatan Motivasi Kerja Pada Perusahaan Jasa Kontruksi Melalui Pendekatan Teori Kebutuhan Maslow. JBTI : Jurnal Bisnis Teori Dan Implementasi.44-53.

Hanafi, A., M. Adam,. dan Ichsan A. (2018). The Effect of Person-Organization Fit (P-O Fit) and Job Satisfaction on Employee Performance with Organizational Commitment as Intervening Variables. International Journal of Education and Research. Vol. 6 No. 11

Harahap, S. F., dan S. Tirtayasa. (2020). Pengaruh Motivasi, Disiplin, Dan Kepuasan Kerja Terhadap Kinerja Karyawan Di PT. Angkasa Pura II (Persero) Kantor Cabang Kualanamu. Jurnal Ilmiah Magister Manajemen. 120-135.

Hartina, Serly. (2020). Pengaruh Budaya Organisasi, Kompensasi Dan Person Organization Fit Terhadap Kinerja Karyawan Dengan Komitmen Organisasi Sebagai Variabel Intervening. Skripsi Gelar Sarjana. IAIN Salatiga

Istanti, D. P. (2018). Pengaruh Person Organization Fit ( P-O Fit ) Terhadap Komitmen Organisasi Dengan Motivasi Kerja Dan Kepuasan Kerja Variabel Intervening. Skripsi Gelar Sarjana. IAIN Salatiga. 
Linking Person Job Fit, Person Organization Fit and Organizational Culture To Employee

Performance In Islamic Banks: The Mediating Role of Job Motivation

Windy Delvyana Wulandari

Page: 125-139

Mewoh, A.D., Pio, R.J., dan Sumayku, S. (2017). Pengaruh Budaya Organisasi Terhadap Kinerja Karyawan Pada PT. Wenang Permai Sentosa. Jurnal Administrasi Bisnis. Vol. 5, No. 5

Musselman, Vernon A dan John H Jackson. 1984. Pengantar Ekonomi Perusahaan. Terjemahan oleh Kusma Wiriadisastra. Jakarta: Penerbit Erlangga.

Nurcahyani, N.M dan I.G.A.Dewi, A. (2016). Pengaruh Kompensasi Dan Motivasi Terhadap Kinerja Karyawan Dengan Kepuasaan Kerja Sebagai Variabel Intervening. E-Jurnal Manajemen Unud. Vol. 5, No.1

Puspita, A dan M. Zakiy. (2020). Aspek Keadilan Organisasi Dan Deviant Workplace Behavior Karyawan. Jurnal Ekonomi Syariah. Vol. 8, No. 1

Puspitasari,R. (2014). Pengaruh Motivasi Kerja Dan Pelatihan Kerja Terhadap Kinerj Karyawan Pada Kantor Pekayanan Pajak Pratama Magelang. Skripsi Gelar Sarjana. Universitas Negeri Yoyakarta.

Putri, W. (2019). Pengaruh Budaya Organisasi, Kompensasi, Motivasi, Dan Person Organization Fit (PO FIT) Terhadap Kinerja Karyawan Melalui Komitmen Organisasi Sebagai Variabel Intervening (Studi Kasus pada BRI Syariah KC Semarang). Skripsi Gelar Sarjana. IAIN Salatiga.

Pramesti, A. I. (2013).Person Organization Fit terhadap Motivasi dan Kinerja Karyawan pada Karyawan PT. Bank Pembangunan Daerah Jawa Timur (Bank Jatim) Cabang Lamongan. Jurnal Administrasi Perkantoran

Rizkia, A. (2020). Pengaruh Person Job Fit, Self Concept, Dan Motivasi Kerja Terhadap Meaningfulness Of Work ( Studi Kasus Pada Lembaga Amil Zakat Kota Semarang ). Jurnal Unissula. 1070-1094.

Safitri, R,A. (2017). Pengaruh Pemberian Insentif, Motivasi, Disiplin Kerja Dan Kepemimpinan Terhadap Kinerja Karyawan Bagian Operasional Pada PT. Bank Negara Indonesia (PERSERO) TBK Kantor Cabang Syariah Palembang. Skripsi Gelar Sarjana. UIN Raden Fatah Palembang.

Sari, E,V.(2013).Pengaruh Budaya Organisasi Terhadap Kinerja Karyawan Pada PT. Taspen (PERSERO) Cabang Yogyakarta. Skripsi Gelar Sarjana. UNY

Sasongko, A.G., Hairudinor., dan M.Riduansyah S. (2021). Pengaruh Budaya Organisasi, Motivasi Kerj Dan Gaya Kepemimpinan Transformasional Terhadap Kinerja Karyawan Dengan Kepuasan Kerja Sebagai Variabel Intervening. Jurnal Bisnis dan Pembangunan. Vol 10. No. 1

Sembiring, Hendri. (2020). Pengaruh Motivasi Dan Lingkungan Kerja Terhadap Kinerja Karyawan Pada Bank Sinarmas Medan. Jurnal Akuntansi dan Manajemen. Vol. 13, No. 1

Septarina, Mifta. (2017). Pengaruh Tingkat Pendidikan Dan Lamanya Bekerja Terhadap Kinerja Karyawan. Skripsi Gelar Sarjana. UIN Raden Fatah Palembang

Setiawan, Kiki, C. (2015). Pengaruh Motivasi Kerja Terhadap Kinerja Karyawan Level Pelaksanaan Di Divisi Operasi PT. Pusri Palembang. Jurnal Psikologi. Vol. 1 No. 2

Sulastri, Eritha., Saladin Ghalib dan Taharuddin T. (2017). Pengaruh Budaya Organisasi , Motivasi , Dan Kepuasan Kerja Terhadap Kinerja Karyawan PT . PLN ( Persero ) Wilayah Kalimantan Selatan dan Kalimantan Tengah Area Kuala Kapuas. Jurnal Bisnis Dan Pembangunan

Sugiyono, P. (2017). Metode Penelitian Kuantitatif. Bandung: CV Aslfabeta.

Utami, V.P dan M. Zakiy. (2020). Linking Leader Member Exchange And Person Supervisor Fit With Employee Performance : The Mediating Role Of Employee Work Engagement. Journal of Leadership in Organizations Vol.2, No. 2

Wulandari, L., dan E, Tjahjaningsih. (2017). Pengaruh Motivasi Dan Kualitas Kehiduan Terhadap Kinerja Pegawai Dengan Mediasi Person Organization Fit. Jurnal Manajemen. Vol. 14 No. 2 
Linking Person Job Fit, Person Organization Fit and Organizational Culture To Employee

Performance In Islamic Banks: The Mediating Role of Job Motivation

Windy Delvyana Wulandari

Page: 125-139

Zakiy, M. (2017). The Barrier and Strategy of Higher Education in Developing Human

Resources. Muqtasid: Jurnal Ekonomi Dan Perbankan Syariah, 8(2), 168-178. https://doi.org/10.18326/muqtasid.v8i2.168-178

Zakiy, M. (2021). The strategy of Islamic economic colleges to prepare their graduates to work in Islamic banks. Higher Education, Skills and Work-Based Learning, ahead-ofp(ahead-of-print). https://doi.org/10.1108/HESWBL-01-2021-0010 